\title{
Effect of Ketoprofen on acute phase protein concentrations in goats undergoing castration
}

\author{
Umit Karademir ${ }^{1 *}$, Ibrahim Akin², Hasan Erdogan ${ }^{3}$, Kerem Ural ${ }^{3}$ and Gamze Sevri Ekren Asici ${ }^{4}$
}

\begin{abstract}
Background: The objective of this study was to determine the effect of ketoprofen on acute phase protein (APPs) concentrations in goats undergoing castration. A total of 16 clinically healthy, male and 12 months old goats were enrolled and each case received ketoprofen (group I) or control (group II) in a randomized fashion. Goats were sedated with Xylazine- $\mathrm{HCl}$, afterwards ketoprofen (3 mg/kg) was injected via jugular vein in group I, whereas physiological saline solution was administered to group II. Goats were castrated by the Burdizzo method. Hematological parameters were determined with a blood cell counter and plasma fibrinogen (Fb), serum haptoglobin (Hp), serum amyloid A (SAA) and ceruloplasmin (Cp) concentrations were measured Millars technique, ELISA kit or p-phenylenediamine oxidase activity prior to castration and throughout the study on 0 to $96 \mathrm{~h}$.

Results: There were no differences in pre-treatment serum Cp, SAA and Fb concentrations among the groups. Contrarily, there were significant differences in plasma $\mathrm{Hp}$ concentrations on 0 to $96 \mathrm{~h}$ onwards post-castration. There were no differences in WBC and PCV between groups. Cp, Fb, and SAA were almost constant or showed slight changes at various stages of the study with no significant differences between groups.

Conclusions: The results revealed that, levels of $\mathrm{Cp}$, Fb and SAA may not be affected by castration such as the confounding parameters similarly to stress. More investigations possessing different surgical or non-surgical castration techniques with larger number of goats and focusing on specific markers for stress are suggested for precise analysis.
\end{abstract}

Keywords: Acute Phase Protein, Castration, Goat, Ketoprofen

\section{Background}

Goats are one of the most important food-producing animal species in developing countries. The castration of male goats is a routine practice in many countries aimed at reducing management problems with aggressive and sexual behaviour, as well as improving meat quality [28]. The main techniques used to castrate goats include surgical or nonsurgical/ischemic (elastrator, burdizzo or emasculatome) methods $[6,8]$. Castration has been shown to elicit inflammatory reactions, physiological stress, suppression of immune function, pain-associated behaviour, and a reduction in performance $[15,16,28]$.

\footnotetext{
* Correspondence: umitkarademir@yahoo.com

${ }^{1}$ Department of Pharmacology and Toxicology, Faculty of Veterinary

Medicine, University of Adnan Menderes, Isikli, Aydin, Turkey

Full list of author information is available at the end of the article
}

The acute phase response (APR) refers to nonspecific and complex reaction of an animal that includes changes in concentration of numerous liver derived plasma proteins, called acute phase proteins (APPs) [20]. APPs are a group of blood proteins that change in concentration in animals subjected to external or internal challenges, such as infection, inflammation, surgical trauma or stress and they are classified as positive (major, moderate and minor) or negative depending on the increase or decrease in the serum concentration, respectively, during the APR [3]. Positive APPs, such as haptoglobin, C-reactive protein, serum amyloid A, ceruloplasmin, fibrinogen, and alpha 1acid glycoprotein, increase in concentration in response to inflammation. The "negative" APPs decrease in concentration in response to inflammation and include proteins like albumin and transferrin [30]. Quantification of APP concentration in plasma or serum can provide valuable 
diagnostic information in the detection, prognosis, and monitoring of disease in several animal species [12]. In addition, the use of APPs for screening in ante- or postmortem inspection to identify animals that should be subjected to a more thorough inspection or to ensure the health of animals prior to entry to the human food chain has been suggested [38].

Nonsteroidal anti-inflammatory drugs (NSAID) including ketoprofen (KTP) are among the most widely drugs in veterinary medicine. They block the activity of cyclooxygenase (COX) enzymes and reduce prostaglandin concentrations through the body. As a consequence, inflammation, pain and fever are reduced [17, 27]. These drugs make them ideal for the clinical management of inflammation and postoperative pain in animals. However, patients condition (eg, respiratory, renal or hepatic insufficiency, dehydration, ascites, coagulopathies, pregnancy or gastric ulcer) and drugs selection must be considered prior to NSAID use due to their potential of adverse effects (eg, antithrombotic activity, gastro-duodenal erosion and ulceration, nephropathy, delayed healing or nonunion of the wound and fracture) $[2,5,27]$. KTP, a propionic acid derivate, is a NSAID which used for the treatment and management symptoms associated with musculoskeletal inflammation and pain in animals [5]. Ruminants have been investigated on the effects of APPs in experimental inflammation models and stress by many authors which the administration of a different dose of lipopolysaccharide [43], turpentine [20], some Pasteurella spp. (e.g., P. haemolytica, P. multocida) [7, 25] and virus spp. (e.g. respiratory syncytial, viral diarrhoea) $[18,22]$, vaccination [11] or restricted feeding [26] and transportation [29]. Although the effects of NSAIDs on APPs in castrated ruminants have been well recognized in some of the prior research articles [9, 40, 41], the effects of NSAIDs on castration induced increases in APPs in goats have not been yet reported and limited data is a currently available. Furthermore there is scarce information in goats on APPs, clearly indicating that there is a need to evaluate goat model. Hence it was hypothesized that ketoprofen has probably effects on some of the positive APPs (Hp, SAA, $\mathrm{Fb}$ and $\mathrm{Cp}$ ) in relation to castration, which is a frequent procedure of goats with Ketoprofen administration.

However, to the best of our knowledge, there is no published data for alterations of APPs in castration of goats with NSAID administration. The aim of this study was to investigate the alterations of some positive APPs ( $\mathrm{Hp}, \mathrm{SAA}, \mathrm{Fb}$ and $\mathrm{Cp}$ ) in castration of goats with KTP administration.

\section{Results}

All goats remained healthy through the study. Through available evidence suggested that castration lead to an increase in APPs in group II. Changes in mean values for serum concentrations of $\mathrm{Hp}, \mathrm{SAA}$ and $\mathrm{Cp}$, plasma concentrations of Fib, WBC and PCV counts were determined over the sample collection period for the two groups (Table 1). There were no differences in pretreatment serum $\mathrm{Cp}$, SAA and Fib concentrations among the groups (Fig. 1).

At the beginning of the study, there was no significant difference regarding $\mathrm{Hp}$ on $24 \mathrm{~h}$ of study. Afterwards through 48 to $96 \mathrm{~h}$ of the completion of the study there was a statistically significant difference between group I and II regarding Hp. The present authors also reported that there was significant group by time interaction regarding $\mathrm{Cp}(P=0,001), \mathrm{Fb}(P=0,003)$ and $\mathrm{WBC}(P=0,001)$ values. For other parameters $(\mathrm{Hp}, \mathrm{SAA}$ and $\mathrm{PCV})$ there was no group by time interaction.

Regarding SAA there was no significance between group I and II throughout the study whereas there was a time interaction in group I among 0.hr and 48 to $96 \mathrm{~h}$. Besides this difference exists at $24^{\text {th }}$ hour in group II. Taking into account $\mathrm{Cp}$ values there was a time interaction through 0 . and 48 to $96 \mathrm{~h}$ in group I. Fibrinogen values possessed significant alterations on 0 and $6^{\text {th }}$ hours. WBC values presented time interaction and group by time interaction $(P<0,001)$.

\section{Discussion}

Regarding veterinary literature in farm animals APPs are important diagnostic indicators of inflammatory disorders also in goats $[1,4,10]$. In the analytical methods of prior study for measuring $\mathrm{Hp}$, SAA, acid soluble glycoprotein (ASG), $\mathrm{Fb}$, and albumin concentrations in goats were validated, in an attempt to assess their response to an inflammatory stimulus in goats [20]. In a recent article establishing reference intervals for acute phase proteins in healthy goats; Hp was be interpreted with caution in unknown pregnancy status, besides it was also suggested that APPs were recommended as useful biomarkers in goat diseases [4]. Hp increases were reported in several diseases of goats; i.e. helminth infestations [42], ruminal acidosis [19], sarcoptic mange [36], besnoidosis [31], coccidiosis [21] and gangrenous mastitis [13]. On the other hand there was no statistically significant differences were found regarding $\mathrm{Hp}$ concentrations in Caprine arthritis encephalitis positive and negative goats [24].

The present authors interest to this subject was aroused following receipt of goats referred for castration. At that time a through literature search revealed studies in cattle subjected to castration in relation to APPs. Contrarily the present authors were unaware of finding documented reports regarding APPs and castration procedure in goats.

As aforementioned above cattle studies largely took a part in the literature. In a prior trial determining the effect of repeated KTP administration to surgically castrated bulls on APPs revealed increased plasma $\mathrm{Hp}$ and 
Table 1 Mean \pm SD concentrations of Hp, SAA, Cp and Fb as well as WBC and PCV counts undergoing castration in male goats ( $n=8$ goats/group)

\begin{tabular}{|c|c|c|c|c|c|c|c|c|c|c|}
\hline & Group & $0 . h r$ & 6. hr & 12.hr & 24. hr & 48. hr & 72. hr & 96. hr & Interactions & $p$ value \\
\hline \multirow[t]{3}{*}{$\mathrm{Hp}(\mathrm{mg} / \mathrm{dl})$} & Ketoprofen & $0,15 \pm 0,10$ & $0,63 \pm 0,24$ & $0,41 \pm 0,09$ & $0,63 \pm 0,33$ & $1,06 \pm 0,86$ & $1,39 \pm 0,92$ & $1,39 \pm 1,15$ & Group & 0,020 \\
\hline & Control & $0,10 \pm 0,11$ & $0,49 \pm 0,08$ & $0,37 \pm 0,12$ & $0,47 \pm 0,33$ & $0,50 \pm 0,17$ & $0,41 \pm 0,22$ & $0,40 \pm 0,23$ & Time & 0,020 \\
\hline & & & & & & & & & Group by Time & 0,212 \\
\hline \multirow[t]{3}{*}{ SAA (mg/dl) } & Ketoprofen & $21,10 \pm 8,01$ & $30,05 \pm 18,86$ & $34,55 \pm 38,34$ & $51,07 \pm 69,60$ & $149,18 \pm 147,04$ & $114,43 \pm 117,21$ & $69,46 \pm 89,74$ & Group & 0,392 \\
\hline & Control & $14,52 \pm 4,42$ & $29,37 \pm 22,90$ & $75,82 \pm 67,67$ & $140,48 \pm 97,44$ & $173,33 \pm 136,34$ & $120,72 \pm 110,72$ & $71,14 \pm 54,55$ & Time & 0,021 \\
\hline & & & & & & & & & Group by Time & 0,433 \\
\hline \multirow[t]{3}{*}{ Cp (mg/dl) } & Ketoprofen & $21,60 \pm 7,88$ & $21,86 \pm 7,17$ & $24,23 \pm 8,62$ & $22,78 \pm 7,34$ & $26,63 \pm 8,67$ & $27,23 \pm 9,55$ & $29,12 \pm 11,16$ & Group & 0,753 \\
\hline & Control & $22,93 \pm 7,58$ & $25,66 \pm 11,52$ & $24,65 \pm 11,27$ & $21,92 \pm 10,82$ & $21,75 \pm 9,19$ & $23,29 \pm 9,73$ & $23,52 \pm 7,22$ & Time & 0,012 \\
\hline & & & & & & & & & Group by Time & 0,001 \\
\hline \multirow[t]{3}{*}{ Fib (mg/dl) } & Ketoprofen & $159,75 \pm 29,64$ & $181,78 \pm 44,50$ & $156,78 \pm 35,78$ & $165,96 \pm 28,20$ & $159,70 \pm 25,10$ & $160,29 \pm 25,48$ & $161,56 \pm 25,34$ & Group & 0,096 \\
\hline & Control & $149,03 \pm 26,18$ & $160,58 \pm 6,97$ & $153,38 \pm 7,51$ & $139,93 \pm 3,83$ & $143,68 \pm 7,59$ & $140,48 \pm 3,56$ & $139,00 \pm 6,14$ & Time & 0,038 \\
\hline & & & & & & & & & Group by Time & 0,003 \\
\hline \multirow[t]{3}{*}{ WBC $\left(\times 10^{9}\right.$ cells/l) } & Ketoprofen & $17,04 \pm 6,47$ & $16,60 \pm 7,49$ & $16,58 \pm 4,44$ & $18,53 \pm 6,50$ & $16,08 \pm 5,52$ & $15,67 \pm 4,77$ & $18,46 \pm 7,25$ & Group & 0,571 \\
\hline & Control & $14,96 \pm 1,20$ & $16,74 \pm 9,99$ & $23,64 \pm 2,15$ & $22,14 \pm 3,35$ & $15,91 \pm 2,99$ & $14,07 \pm 2,35$ & $17,35 \pm 2,09$ & Time & 0,000 \\
\hline & & & & & & & & & Group by Time & 0,000 \\
\hline \multirow[t]{3}{*}{ PCV (\%) } & Ketoprofen & $14,20 \pm 2,99$ & $12,01 \pm 3,19$ & $16,15 \pm 2,40$ & $16,52 \pm 2,53$ & $14,54 \pm 2,18$ & $14,72 \pm 2,53$ & $14,09 \pm 1,75$ & Group & 0,112 \\
\hline & Control & $14,48 \pm 0,58$ & $13,29 \pm 3,89$ & $14,00 \pm 0,97$ & $14,96 \pm 1,39$ & $13,22 \pm 1,50$ & $13,36 \pm 1,54$ & $13,18 \pm 0,67$ & Time & 0,036 \\
\hline & & & & & & & & & Group by Time & 0,630 \\
\hline
\end{tabular}




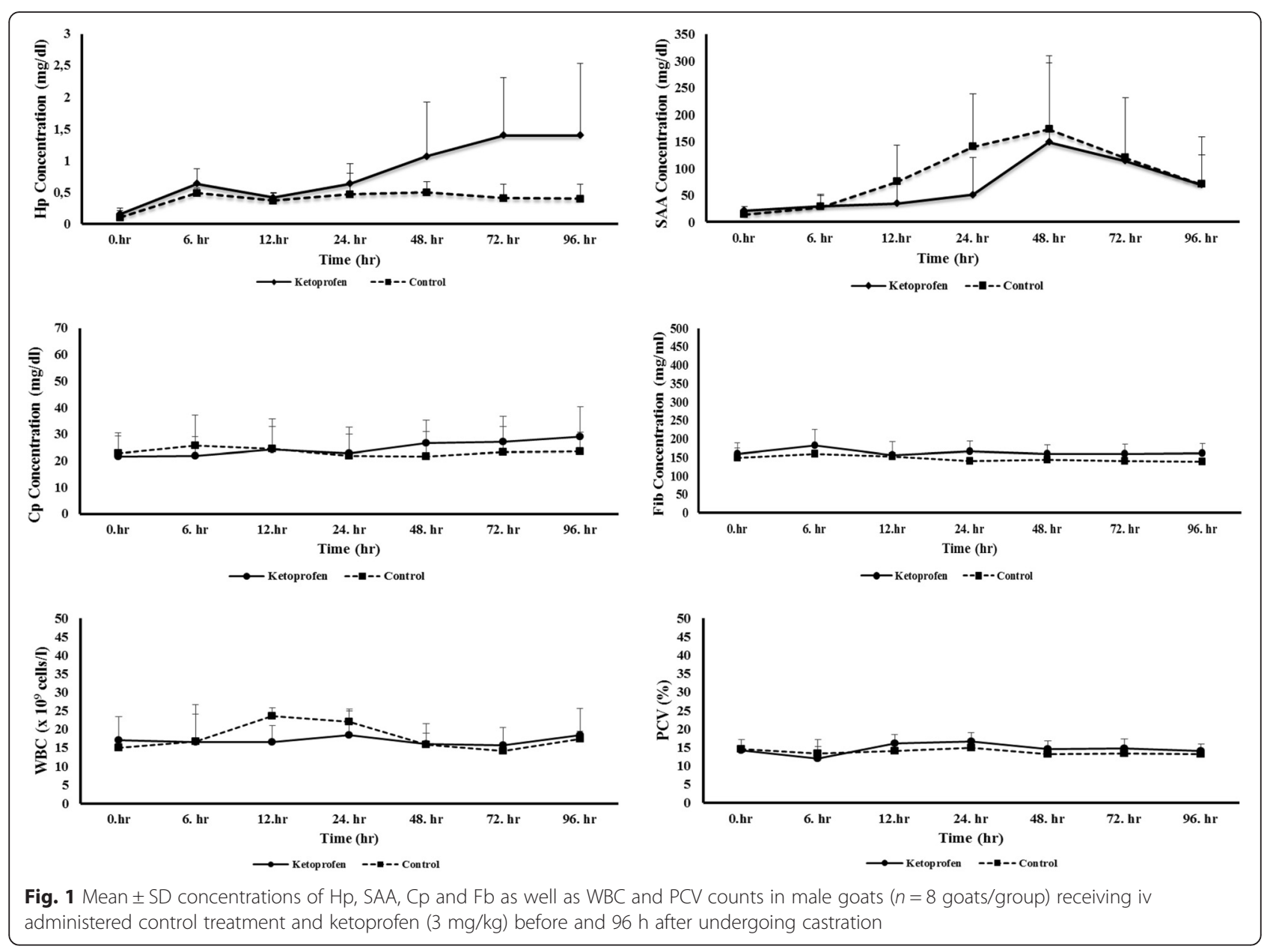

Fb concentrations were increased $(P<0.05)$ on day 3 in the castration groups in comparison to the controls, in which were attributed to tissue trauma induced by castration. In the latter study surgical castration increased plasma cortisol and acute-phase proteins. On the other hand repeated KTP dose $24 \mathrm{~h}$ after treatment did not have influence on alteration in APPs [41]. Similarly, the effects of carprofen administration before banding or burdizzo castration of bulls on APPs were investigated. In that study $\mathrm{Hp}$ concentrations presented similarity $(P=0.58)$ among treatments before the time of castration. Afterwards on day 1, no differences in Hp concentration was detected and castrated and control groups. On day 3 band group showed elevated $(P<0.05) \mathrm{Hp}$ in comparison to control. On the other hand no differences in $\mathrm{Hp}$ concentrations were detected among treatments on d 7, 14, 21, and 28. finally on day 35 banded group showed greater $(P<0.05) \mathrm{Hp}$ concentrations compared with Band $+\mathrm{C}$ and control groups [34].

In the present study, Hp was the solely affected APPs deemed statistically significant in KTP administered goats $(P<0.05)$ in comparison to controls. This may be briefly explained. Although recognized of the concentrations of the $\mathrm{Hp}, \mathrm{Cp}$ and $\mathrm{Fb}$ may be useful in the diagnosis of tissue injury [35], according to the results of the present study unlike $\mathrm{Hp}$, levels of $\mathrm{Cp}, \mathrm{Fb}$, and SAA may not be affected by tissue injury through Burdizzo castration. Increased $\mathrm{Hp}$ levels observed in this study might be related to the immediate tissue trauma, inflammation, and probably psychological (pain) stress in response to castration [32, 34]. Pang et al. [33] reported banding or burdizzo castration did not effect plasma $\mathrm{Hp}$ and $\mathrm{Fb}$ levels. Previous reports presented an increase in $\mathrm{Hp}$ and $\mathrm{Fb}$ levels on days 1,3 , and 7 post-castration in younger animals [14, 15, 34, 40]. Horadagoda et al. [23] reported that APPs, such as SAA and Hp are excellent markers for indicating acute inflammatory conditions in cattle. Pang et al. [33] stated that unchanged $\mathrm{Hp}$ and $\mathrm{Fb}$ levels in castrates, might be related to the dynamics (increased followed by a return to normal) of APPs during injury. In addition WBC and PCV values were deemed statistically unaffected between groups, revealed that tissue damage or injury was not significant, nor stress leukogram appeared in castrated animals participated in the present study. 


\section{Conclusion}

$\mathrm{Cp}, \mathrm{Fb}$ and SAA were almost constant or showed slight changes at various stages of the study with no significant difference between groups. Levels of $\mathrm{Cp}, \mathrm{Fb}$ and SAA is not affected by castration such as the confounding parameters similarly to stress. More investigations possessing different surgical or non-surgical castration techniques with larger number of goats and focusing on specific markers for stress are suggested for precise analysis.

\section{Methods}

The present authors ensured that their manuscript reported adheres to the arrive guidelines for the reporting of animal experiments. This statement address to their manuscript that these guidelines were followed.

\section{Animals and housing}

The study was approved by the Animal Ethics Committee of Adnan Menderes University (with no: $64583101 / 2015 / 030$ ). A total of 16 clinically healthy, male, 12 months old and weighing 25-30 kg Alpine Goats were used in the study. The animals were obtained from the faculty farm, belonging to the Adnan Menderes University, Faculty of Veterinary Medicine. Written owner consent was available through farm manager. All goats were considered clinically healthy after a thorough clinical check together with blood and serum chemistry profile and urinalysis. The goats were given a quarantine anthelmintic drench (ricabendazole - Rizal Enjectabl, Sanovel, Istanbul, Turkey; ivermectine - Vilmectin ${ }^{\circ}$ Enjektabl, Vilsan Veteriner Ilaclari, Ankara, Turkey) at the manufacturers recommended doses in an animal house for a 2-week period before the commencement of the study. The animals were fed twice daily at 8:00 and 16:00 with a ration of commercial goat pellets and alfa alfa hay. Water was supplied ad libitum and mineral licks were provided for free access.

\section{Study design, castration and treatment}

Goats were enrolled, and each case received KTP (group I, $n=8$ ) or control (group II, $n=8$ ) in a randomized fashion, similarly to what have been described elsewhere [39]. Each group of goats was kept in suitable single boxes, which were then marked by ear tags. Goats were sedated with $0.3 \mathrm{mg} / \mathrm{kg}$ dose Xylazine- $\mathrm{HCl}$ intravenously [8]. Afterwards KTP $(3 \mathrm{mg} / \mathrm{kg})$ was injected via jugular vein in group I, indeed physiological saline solution $(1 \mathrm{ml})$ was administered to group II. Goats were castrated by the Burdizzo (emasculatome) method. All castrations were performed by the same surgeon, who was experienced with the technique.
Collection of blood samples and laboratory analyses

Blood samples (4 ml/sample) from all goats were collected from the jugular vein via 20 -gauge $25 \mathrm{~mm}$ needles into 2 evacuated tubes (one that contained EDTA-K, and another that contained a coagulation activator). Blood samples were obtained $30 \mathrm{~min}$ before injection of Xylasine- $\mathrm{HCl}$ (baseline: time 0) and 6, 12, 24, 48, 72, $96 \mathrm{~h}$ after the end of castration.

Blood samples contained EDTA-K were used to determine hematologic variables and $\mathrm{Fb}$ concentration. Hematologic parameters were performed with a blood cell counter (Abacus Junior Vet 5, Diatron Messtechnik $\mathrm{GmbH}$, Vienna, Austria) calibrated for goat blood; WBC and PCV counts were used for statistical analysis. Plasma $\mathrm{Fb}$ concentration was measured via the Millars technique [1]. Plasma $\mathrm{Fb}$ concentrations and hematologic variables were determined within $6 \mathrm{~h}$ of the same day.

Other blood samples contained a coagulation activator were used to determine other APPs. Each blood sample was centrifuged at $3000 \mathrm{~g}$ for $10 \mathrm{~min}$ and the resulting serum was transferred to plastic tubes and stored at $-20{ }^{\circ} \mathrm{C}$ for analysis. All serum samples were analysed on the same day after the sample collection period.

Serum Hp and SAA concentrations were measured with a commercially available ELISA kit (Cat no: TP801 and TP-802 for Hp and SAA, respectively, Tridelta Development Ltd., Kildare, Ireland) at the manufacturers' recommended assay procedure. $\mathrm{Hp}$ and SAA concentrations were evaluated reference value versus at 630 and $450 \mathrm{~nm}$, respectively, in a microplate reader (ELX-808, BioTek Instruments Inc., Vermont, USA) as mentioned in the method. Free hemoglobin possesses peroxidase activity that might be inhibited at low $\mathrm{pH}$. Hp present in the blood sample reacts with hemoglobin, with a low $\mathrm{pH}$ demonstrates peroxidase activity by bounding to hemoglobin. SAA kit, a solid sandwich Enzyme Linked Immuno Sorbent Assay (ELISA) performed in automated format. By the manufacturer a monoclonal antibody specific for SAA has been coated onto the wells of the microtitre strips. Obtained specimens [involving calibrators of known SAA content], were incubated into micro-wels at $37{ }^{\circ} \mathrm{C}$ together with a HRP labeled anti-SAA antibody. The presence SAA was captured between the the labeled antibody and coated microplate. The plate was washed following sampling and antibody-HRP incubation were removed within unbound material. Afterwards adding TMB, a blue product generating the colour, to those of direct proportion to the amount of SAA present in the original sample/calibrator. The reaction was finalized within the addition of stop reagent. The serum concentration of $\mathrm{Cp}$ was determined by measuring $p$-phenylenediamine oxidase activity as described by Ravin [37] with a spectrophotometer (UV-1601 UV-VIS Spectrophotometer, Shimadzu Corporation Tokyo, Japan). 


\section{Statistical analysis}

Statistical analysis was performed with a statistical software program (SPSS-Version 21.0, SPSS Inc., Chicago, USA). A Kolmogorov-Smirnov test was used to assess all variables for normality. For data that were not distributed normally, transformations were applied to normalize the distribution. The effects of time, group (i.e., treatment), and group-by-time interaction were assessed via and ANOVA for repeated measures. When a significant group-by-time interaction was detected, Tukey multiple comparison tests were used to compare treatments within each time period. Within each group, the baseline value was compared with the values at various time points after castration and isotonic- $\mathrm{NaCl} /$ ketoprofen by use of the Bonferroni correction method. Results were considered significant at values of $P<0.05$. Comparisons within and between groups were based on the final statistical model.

\section{Abbreviations \\ APPs, Acute phase proteins; APR, The acute phase response; ASG, Acid soluble glycoprotein; Cp, Ceruloplasmin; Fb, Fibrinogen; Hp, Serum haptoglobin; KTP, Ketoprofen; NSAID, Nonsteroidal anti-inflammatory drugs; SAA, Serum amyloid A}

\section{Acknowledgements}

The authors would like to thank Prof. Pinar Alkim Ulutas for her assistance.

\section{Funding}

This study was self-funded, no external resources were used.

\section{Availability of data and material}

The datasets supporting the conclusions of this article are included within the article and its additional files.

\section{Authors' contributions \\ All authors have made substantial contributions to all of the following: the conception and design of the study $(U K, \mid A)$, the animal phase of the experiments (IA, UK, HE), the analytical phase of the study (UK, KU, GSEA), drafting the article (UK, KU). All authors have read and approved the final manuscript.}

\section{Competing interests}

The authors declare that they have no competing interests.

\section{Consent for publication}

Not applicable.

\section{Ethics approval and consent to participate}

The study was approved by the Animal Ethics Committee of Adnan Menderes University (with no: 64583101/2015/030).

\section{Author details}

${ }^{1}$ Department of Pharmacology and Toxicology, Faculty of Veterinary Medicine, University of Adnan Menderes, Isikli, Aydin, Turkey. 'Department of Surgery, Faculty of Veterinary Medicine, University of Adnan Menderes, Isikli Koyu, Aydin, Turkey. ${ }^{3}$ Department of Internal Medicine, Faculty of Veterinary Medicine, University of Adnan Menderes, Isikli Koyu, Aydin, Turkey.

${ }^{4}$ Department of Biochemistry, Faculty of Veterinary Medicine, University of Adnan Menderes, Isikli Koyu, Aydin, Turkey.

Received: 23 October 2015 Accepted: 16 June 2016 Published online: 23 June 2016

\section{References}

1. Benjamin MM. Fibrinogen, third ed. Outline of Veterinary Clinical Pathology. USA: The lowa State University Press; 1978. p. 117.

2. Bergh MS, Budsberg SC. The coxib NSAIDs: potential clinical and pharmacologic importance in veterinary medicine. J Vet Intern Med. 2005; 19(5):633.

3. Ceciliani F, Ceron JJ, Eckersall PD, Sauerwein H. Acute phase proteins in ruminants. J Proteom. 2012;75:4207-31.

4. Cray C, Zaias J, Altman NH. Acute phase response in animals: a review. Comp Med. 2009;59(6):517

5. Curry SL. Nonsteroidal anti-inflammatory drugs: a review. J Am An Hos Assoc. 2005;41:298-309.

6. Dawson LJ. Preferred Management Practices. In: Solaiman SG, editor. Goat Science and Production. lowa: Blackwell Publishing; 2010.

7. Dowling A, Hodgson JC, Schock A, Donachie W, Eckersall PD, McKendrick IJ. Experimental induction of pneumonic pasteurellosis in calves by intratracheal infection with Pasteurella multocida biotype A:3. Res Vet Sci. 2002;73:37-44.

8. Duncanson GR. Veterinary Treatment of Sheep and Goats. Cambridge: CABI; 2012

9. Earley B, Crowe MA. Effects of ketoprofen alone or in combination with local anesthesia during the castration of bull calves on plasma cortisol, immunological, and inflammatory responses. J Anim Sci. 2002;80:1044-52.

10. Eckersall PD, Bell R. Acute phase proteins: biomarkers of infection and inflammation in veterinary medicine. Vet J. 2010;185:23-7.

11. Eckersall PD, Lawson FP, Kyle CE, Waterston M, Bence L, Stear MJ, Rhind SM. Maternal undernutrition and the ovine acute phase response to vaccination. BMC Vet Res. 2008;4:1-10.

12. Eckersall PD. Recent advances and future prospects for the use of acute phase proteins as markers of disease in animals. Rev Med Vet. 2000;151:577-84.

13. El-Deeb WM. Clinicobiochemical investigations of gangrenous mastitis in does: immunological responses and oxidative stress biomarkers. J Zhejiang Univ Sci B. 2013;14(1):33-9.

14. Faulkner DB, Eurell T, Tranquilli WJ, Ott RS, Ohl MW, Cmarik GF, Zinn G. Performance and health of weanling bulls after butorphanol and xylazine administration at castration. J Anim Sci. 1992;70:2970-4.

15. Fisher $\mathrm{AD}$, Crowe MA, Alonso de la Varga ME, Enright WJ. Effect of castration method and the provision of local anaesthesia on plasma cortisol, scrotal circumference, growth and feed intake of bull calves. J Anim Sci. 1996;74:2336-43.

16. Fisher AD, Crowe MA, O'Nuallain EM, Monaghan ML, Larkin JA, Kiely PO, Enright WJ. Effects of cortisol on in vitro interferon- $\gamma$ production, acute phase proteins, growth, and feed intake in a calf castration model. J Anim Sci. 1997;75:1041-7

17. Friton GM, Cajal C, Ramirez-Romero R. Long-term effects of meloxicam in the treatment of respiratory disease in fattening cattle. Vet Rec. 2005;156:809-11.

18. Ganheim C, Hulten C, Carlsson U, Kindahl H, Niskanen R, Waller KP. The acute phase response in calves experimentally infected with Bovine Viral Diarrhoea Virus and/or Mannheimia Haemolytica. J Vet Med B. 2003;50(4):183-90.

19. González FHD, Ruipérez FH, Sánchez JM, Souza JC, Martínez-Subiela S, Cerón JJ. Haptoglobin and serum amyloid a in subacute ruminal acidosis in goats. Rev Med Vet Zoot. 2010;57:168-77.

20. Gonzalez FHD, Tecles F, Martinez-Subiela S, Tvarijonaviciute A, Soler L, Ceron JJ. Acute phase protein response in goats. J Vet Diagn Invest. 2008;20:580-4.

21. Hashemnia M, Khodakaram-Tafti A, Razavi SM, Nazifi S. Alternative formats. Korean J Parasitol. 2011:49(3):213-9.

22. Heegaard PMH, Godson DL, Toussaintc MJM, Tjùrnehùj K, Larsen LE, Viuff $B$, Rùnsholt $L$. The acute phase response of haptoglobin and serum amyloid $A$ (SAA) in cattle undergoing experimental infection with bovine respiratory syncytial virus. Vet Immun Immunopat. 2000;77:151-9.

23. Horadagodo NU, Knox KM, Gibbs HA, Reid SW, Horadagoda A, Edwards SE, Eckersall PD. Acute phase proteins in cattle: discrimination between acute and chronic inflammation. Vet Rec. 1999;144:437-41.

24. Kaba J, Stefaniak T, Bagnicka E, Czopowicz M. Haptoglobin in goats with caprine arthritis-encephalitis. Centr Eur J Immunol. 2011;36:76-8.

25. Katoh $\mathrm{N}$, Nakagawa $\mathrm{H}$. Detection of haptoglobin in the high-density lipoprotein and the very high-density lipoprotein fractions from sera of calves with experimental pneumonia and cows with naturally occurring fatty liver. J Vet Med Sci. 1999;6:119-24.

26. Katoh N, Oikawa S, Oohashi T, Takahashi Y, Itoh F. Decreases of apolipoprotein B-100 and A-I concentrations and induction of haptoglobin and serum amyloid A in nonfed calves. J Vet Med Sci. 2002;564:51-5. 
27. Mathews KA. Nonsteroidal anti-inflamatory analgesics: a review of current practice. J Vet Emerg Crit Care. 2002;12:89-97.

28. Molony V, Kent JE, Robertson IS. Assessment of acute and chronic pain after different methods of castration of calves. Appl Anim Behav Sci. 1995;46:33-48.

29. Murata $\mathrm{H}$, Miyamoto T. Bovine haptoglobin as a possible immunomodulator in the sera of transported calves. Br Vet J. 1993;149:277-83.

30. Murata H, Shimada N, Yoshioka M. Current research on acute phase proteins in veterinary diagnosis: an overview. Vet J. 2004;168:24-40.

31. Nazifi S, Oryan A, Namazi F. Hematological and serum biochemical analyses in experimental caprine besnoitiosis. Korean J Parasitol. 2011;49(2):133-8.

32. Obled C. Amino acid requirements in inflammatory states. Can J Anim Sci. 2003;83:365-73.

33. Pang WY, Earley B, Gath V, Crowe MA. Effect of banding or burdizzo castration on plasma testosterone, acute-phase proteins, scrotal circumference, growth, and health of bulls. Livest Sci. 2008;117:79-87.

34. Pang WY, Earley B, Sweeney T, Crowe MA. Effect of carprofen administration during banding or burdizzo castration of bulls on plasma cortisol, in vitro interferon-gamma production, acute-phase proteins, feed intake, and growth. J Anim Sci. 2006;84:351-9.

35. Pfeffer A, Rogers KM. Acute phase response of sheep: changes in the concentrations of ceruloplasmin, fibrinogen, haptoglobin and the major blood cell types associated with pulmonary damage. Res Vet Sci. 1989;46:118-24.

36. Rahman MM, Lecchi C, Fraquelli C, Sartorelli P, Ceciliani F. Acute phase protein response in Alpine ibex with sarcoptic mange. Vet Parasitol. 2010; 168(3):293-8.

37. Ravin HA. An improved colorimetric enzymatic assay of ceruloplasmin. J Lab Clin Med. 1961;58:161-8.

38. Saini PK, Webert DW. Application of acute phase reactants during antemortem and post-mortem meat inspection. J Am Vet Med Assoc. 1991; 198:1898-901.

39. Thomas J, Doherty WA Will, Barton W, Rohrbach DR, Dennis Geiser R. Effect of morphine and flunixin meglumine on isoflurane minimum alveolar concentration in goats. Vet Anaesth Analg. 2004;31:97-101.

40. Ting ST, Earley B, Crowe MA. Effect of repeated ketoprofen administration during surgical castration of bulls on cortisol, immunological function, feed intake, growth, and behavior. J Anim Sci. 2003;81:1253-64.

41. Ting STL, Earley B, Hughes JML, Crowe MA. Effect of ketoprofen, lidocaine local anesthesia, and combined xylazine and lidocaine caudal epidural anesthesia during castration of beef cattle on stress responses, immunity, growth, and behavior. J Anim Sci. 2003;81(5):1281-93.

42. Ulutas PA, Voyvoda H, Ulutas B, Aypak S. Haptoglobin, serum amyloid-a and ceruloplasmin concentrations in goats with mixed helminth infection. Acta Paras Tur. 2008;32:229-33.

43. Werling D, Sutter F, Arnold M, Kun G, Tooten PCJ, Gruys E, Kreuzer M. Characterisation of the acute phase response of heifers to a prolonged low dose infusion of lipopolysaccharide. Res Vet Sci. 1996;61:252-7.

\section{Submit your next manuscript to BioMed Central and we will help you at every step:}

- We accept pre-submission inquiries

- Our selector tool helps you to find the most relevant journal

- We provide round the clock customer support

- Convenient online submission

- Thorough peer review

- Inclusion in PubMed and all major indexing services

- Maximum visibility for your research

Submit your manuscript at www.biomedcentral.com/submit

C Biomed Central 